\title{
Unusual Clinical Presentation of Gastrointestinal Clear Cell Sarcoma
}

\author{
Grigory A. Raskin ${ }^{a} \quad$ Kazimir M. Pozharisskia ${ }^{a}$ Aglaya G. Iyevlevab, c \\ Ivan V. Rikov $^{d}$ Rashida V. Orlovad Evgeny N. Imyanitov ${ }^{\text {b-e }}$ \\ ${ }^{a}$ Russian Research Center for Radiology and Surgical Technologies, b N.N. Petrov Institute \\ of Oncology, 'Saint Petersburg State Pediatric Medical University, d'Saint Petersburg State \\ University, Medical Faculty, and eI.I. Mechnikov North-Western State Medical University, \\ Saint Petersburg, Russia
}

\section{Key Words}

ATF1 - Cancer of unknown primary site $\cdot$ Ewing's sarcoma $\cdot$ EWSR1 $\cdot$ Gastrointestinal clear cell sarcoma $\cdot$ Melanoma $\cdot$ Polymerase chain reaction $\cdot$ Review $\cdot$ Translocation

\begin{abstract}
Background: Use of molecular assays is gradually becoming a mandatory part of the clinical management of soft tissue tumors, however the choice and the interpretation of these tests may present a challenge. Summary: This report demonstrates an unusual presentation of sarcoma, which was initially diagnosed as a tumor of unknown primary site. Given the presence of vimentin, Fli-1, CD99 and S100 markers, lack of immunostaining for melan A, HMB45, MITF, synaptophysin, CD56, myf4, CKAE1/3 and WT-1, as well as the presence of EWSR1 translocation determined by a break-apart FISH assay, Ewing's sarcoma (ES) diagnosis seemed to be well justified. However, polymerase chain reaction testing for ES-specific rearrangements (EWSR1/FLI1, EWSR1/ERG, EWSR1/ETV1, EWSR1/ETV4, EWS/FEV) failed to confirm the ES origin of the neoplastic tissue. We further considered clinical, morphological, immunohistochemical and molecular diagnostic features of other types of EWSR1-rearranged sarcomas and performed molecular testing for gastrointestinal clear cell sarcoma. The polymerase chain reaction assay revealed EWSR1ex7/ATF1ex5 fusion, thus confirming the latter diagnosis. Subsequent high-precision computed tomography of the abdominal cavity revealed a $5-\mathrm{cm}$ tumor of the small bowel, which was subjected to surgical resection. Key Message: This report exemplifies that the use of anonymous cytogenetic assays, such as break-apart FISH EWSR1 testing, may not be sufficient even in case of a perfect match with relevant morphological and immunohistochemical tumor features. Practical Implications: Explicit identification of the translocation gene partners is indeed important for proper sarcoma diagnosis management.
\end{abstract}




\section{Gastro Intestinal Tumors}

\begin{tabular}{l|l}
\hline Gastrointest Tumors 2015;2:83-88 \\
\hline DOI: 10.1159/000430881 & $\begin{array}{l}\text { @ 2015 S. Karger AG, Basel } \\
\text { www.karger.com/gat }\end{array}$ \\
\hline
\end{tabular}

Raskin et al.: Unusual Clinical Presentation of Gastrointestinal Clear Cell Sarcoma

\section{Introduction}

Gastrointestinal clear cell sarcoma (CCS) is an exceptionally rare tumor, with only a few dozen cases described in the literature [1,2]. The diagnosis of CCS is complicated as it requires a combination of morphological, immunohistochemical and molecular techniques [3]. Here we describe an unusual presentation of CCS of the small intestine which manifested with nonspecific symptoms and was initially considered as metastatic sarcoma of unknown primary site.

\section{Case Report}

The 21-year-old patient was initially forwarded to a cardiology unit due to dyspnea, tachycardia, fatigue and night fever. These symptoms had been triggered by recent tonsillitis, so the patient was suspected to suffer from septic endocarditis and therefore received intensive antibacterial therapy. Further examination by spiral computed tomography revealed abdominal lymphadenopathy, while no abnormalities were detected by esophagogastroscopy and colonoscopy. Diagnostic laparoscopic biopsy of an affected lymph node was subsequently performed.

Morphological examination of the obtained specimen revealed features of sarcoma (fig. 1). Given immunopositivity with antibodies for vimentin, S100 (fig. 1c), CD99 and Fli-1 (fig. 1d), lack of reactivity for melan A, HMB45, MITF, synaptophysin, CD56, myf4, CKAE1/3 and WT-1, as well as presence of EWSR1 translocation determined by a break-apart FISH assay (fig. 2a), Ewing's sarcoma (ES) diagnosis was assigned to this
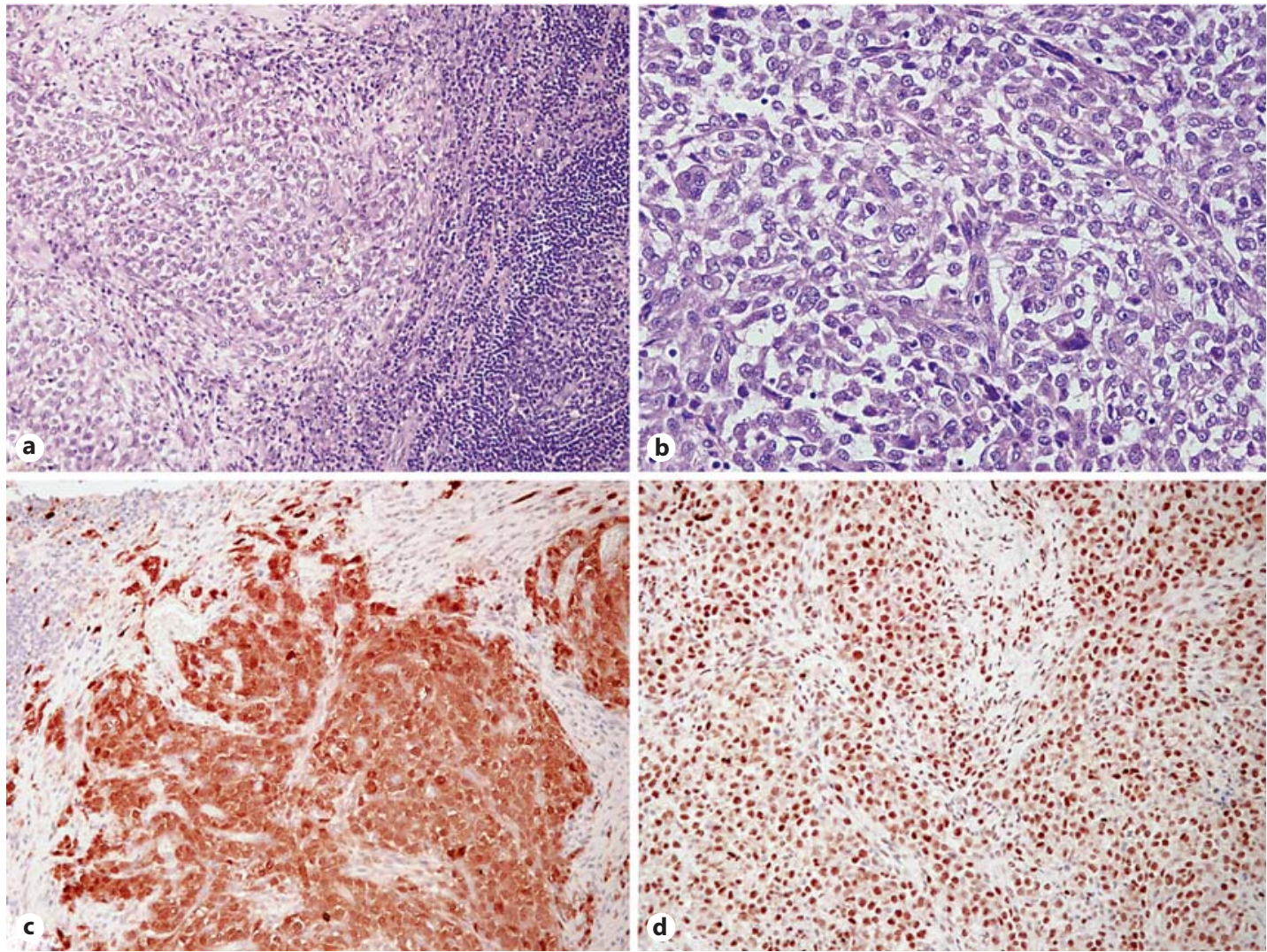

Fig. 1. Lymph node metastasis of CCS. a H\&E staining. $\times 200$. b H\&E staining revealed presence of multinucleated cells. $\times 400$. c Immunohistochemical staining with S100 polyclonal antibody (dilution 1:2,500, Dako). $\times 200$. d Immunohistochemical staining with Fli-1 antibody (clone MRQ-1, dilution 1:50, Cell Marque) $\times 200$. 
Gastro

Intestinal

Tumors
Gastrointest Tumors 2015;2:83-88

DOI: $10.1159 / 000430881$



2015 S. Karger AG, Basel www.karger.com/gat

Raskin et al.: Unusual Clinical Presentation of Gastrointestinal Clear Cell Sarcoma
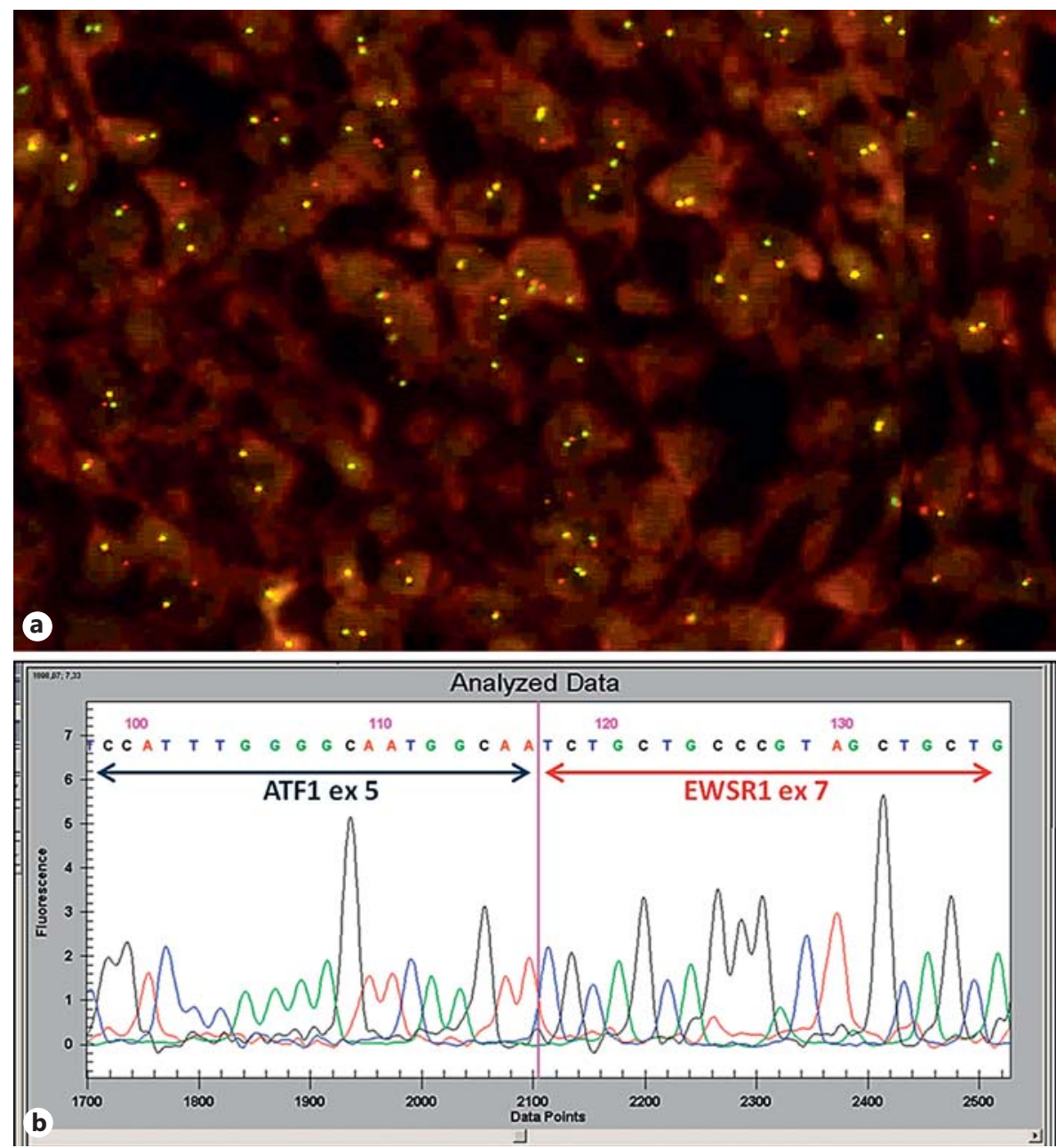

Fig. 2. a EWSR1 translocation revealed by the Vysis LSI dual color break-apart probe. $\times 1,000$. b Nucleotide sequence of the chimeric EWSR1ex7/ATF1ex5 transcript.
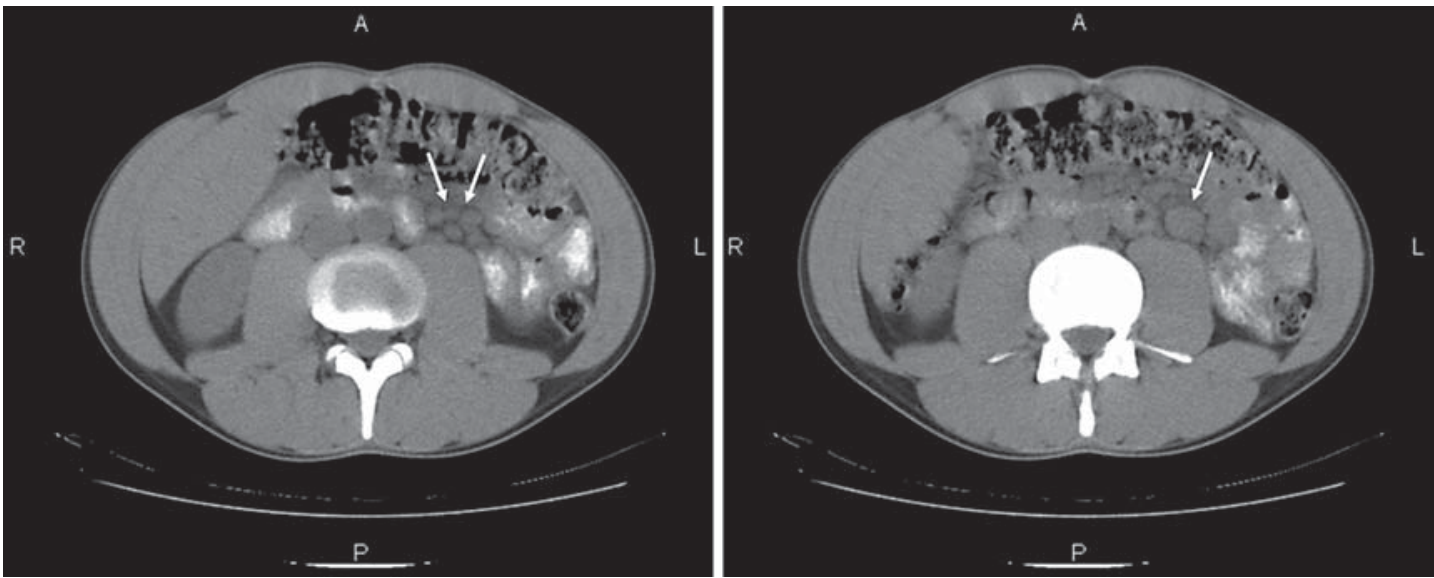

Fig. 3. Abdominal CT scans revealed tumor nodules (marked by arrows), which formed a conglomerate approximately $5 \mathrm{~cm}$ in diameter. The results of image analysis are in agreement with the macroscopic appearance of the tumor upon surgical resection (data not shown). 
Table 1. Differential diagnosis of tumors bearing EWSR1 translocation $[3,5,14]$

\begin{tabular}{|c|c|c|c|c|c|c|c|}
\hline Characteristics & ES & $\begin{array}{l}\text { CCS, common } \\
\text { type }\end{array}$ & $\begin{array}{l}\text { CCS, gastro- } \\
\text { intestinal type }\end{array}$ & $\begin{array}{l}\text { Myoepithelial } \\
\text { carcinoma }\end{array}$ & $\begin{array}{l}\text { Desmoplastic } \\
\text { small round } \\
\text { cell tumor }\end{array}$ & $\begin{array}{l}\text { Extraskeletal } \\
\text { myxoid } \\
\text { chondro- } \\
\text { sarcoma }\end{array}$ & $\begin{array}{l}\text { Present } \\
\text { observation }\end{array}$ \\
\hline $\begin{array}{l}\text { Anatomic } \\
\text { location }\end{array}$ & $\begin{array}{l}\text { bones }(80 \%) \\
\text { or virtually } \\
\text { any anatomic } \\
\text { site }(20 \%)\end{array}$ & $\begin{array}{l}\text { extremities, } \\
\text { often } \\
\text { associated with } \\
\text { tendons or } \\
\text { aponeuroses }\end{array}$ & $\begin{array}{l}\text { small bowel, } \\
\text { stomach, colon }\end{array}$ & $\begin{array}{l}\text { limbs }(75 \%), \\
\text { trunk, head } \\
\text { and neck; } \\
\text { rarely in bones } \\
\text { or visceral } \\
\text { organs }\end{array}$ & $\begin{array}{l}\text { abdominal } \\
\text { cavity, retro- } \\
\text { peritoneum }\end{array}$ & $\begin{array}{l}\text { proximal } \\
\text { extremities, } \\
\text { limb; rarely } \\
\text { in retroperi- } \\
\text { toneum, pleura, } \\
\text { bones }\end{array}$ & $\begin{array}{l}\text { abdominal } \\
\text { cavity } \\
\text { (small } \\
\text { bowel) }\end{array}$ \\
\hline $\begin{array}{l}\text { Median age at } \\
\text { presentation }\end{array}$ & 20 years & $20-40$ years & $20-40$ years & 40 years & $20-30$ years & 50 years & 21 years \\
\hline $\begin{array}{l}\text { Clear cell } \\
\text { appearance }\end{array}$ & often present & present & present & often present & absent & $\begin{array}{l}\text { may be } \\
\text { present }\end{array}$ & present \\
\hline $\begin{array}{l}\text { Osteoclast-like } \\
\text { cells }\end{array}$ & absent & often present & often present & usually absent & usually absent & usually absent & present \\
\hline PAS stain & positive & positive & positive & negative & negative & positive & positive \\
\hline S100 expression & $\begin{array}{l}\text { may be } \\
\text { positive }\end{array}$ & positive & positive & positive & $\begin{array}{l}\text { usually } \\
\text { negative }\end{array}$ & $\begin{array}{l}\text { positive in } \\
20 \% \text { of cases }\end{array}$ & positive \\
\hline $\begin{array}{l}\text { Melanocytic } \\
\text { markers (melan A, } \\
\text { HMB45, MITF) }\end{array}$ & negative & positive & often negative & negative & negative & negative & negative \\
\hline Fli-1 expression & positive & $\begin{array}{l}\text { usually } \\
\text { negative }\end{array}$ & $\begin{array}{l}\text { usually } \\
\text { negative }\end{array}$ & $\begin{array}{l}\text { usually } \\
\text { negative }\end{array}$ & $\begin{array}{l}\text { usually } \\
\text { negative }\end{array}$ & $\begin{array}{l}\text { usually } \\
\text { negative }\end{array}$ & positive \\
\hline CD99 expression & positive & $\begin{array}{l}\text { usually } \\
\text { negative }\end{array}$ & $\begin{array}{l}\text { usually } \\
\text { negative }\end{array}$ & $\begin{array}{l}\text { usually } \\
\text { negative }\end{array}$ & positive & $\begin{array}{l}\text { usually } \\
\text { negative }\end{array}$ & positive \\
\hline $\begin{array}{l}\text { Cytokeratin } \\
\text { expression }\end{array}$ & $\begin{array}{l}\text { may be } \\
\text { positive }\end{array}$ & negative & negative & positive & positive & $\begin{array}{l}\text { usually } \\
\text { negative }\end{array}$ & negative \\
\hline $\begin{array}{l}\text { EWSR1 gene rear- } \\
\text { rangement (FISH } \\
\text { break-apart assay) }\end{array}$ & positive & positive & positive & positive & positive & positive & positive \\
\hline $\begin{array}{l}\text { EWSR1 fusion } \\
\text { partners }\end{array}$ & $\begin{array}{l}\text { FLI1 (85\%), } \\
\text { ERG, ETV1, } \\
\text { ETV4, FEV }\end{array}$ & ATF1, CREB1 & ATF1, CREB1 & $\begin{array}{l}\text { POU5F1, } \\
\text { PBX1, ZNF444 }\end{array}$ & WT1 & NR4A3 & ATF1 \\
\hline
\end{tabular}

case. However, comprehensive polymerase chain reaction testing for ES-specific rearrangements (EWSR1/ FLI1, EWSR1/ERG, EWSR1/ETV1, EWSR1/ETV4, EWS/FEV) [4] failed to confirm the ES origin of the neoplastic tissue. EWSR1 translocations are known to occur in other types of tumors, including CCS, myoepithelial carcinomas, desmoplastic small round cell tumors, extraskeletal myxoid chondrosarcomas, myxoid liposarcomas, angiomatoid fibrous histiocytomas, B-lymphoblastic leukemia, etc. [5]. Based on the combination of clinical, morphological and immunohistochemical features (table 1), we further considered the diagnosis of gastrointestinal CCS and performed polymerase chain reaction analysis for EWSR1/ATF1 and EWSR1/CREB1 fusions [6]. This led to the identification of the EWSR1ex7/ATF1ex5 translocation, as confirmed by DNA sequencing (fig. 2b). Subsequently, the patient's abdominal cavity was again subjected to a high-precision computed tomography. This allowed to reveal the tumor conglomerate in the small intestine (approximately $5 \mathrm{~cm}$ in diameter), which was excised by surgical intervention (fig. 3). The microscopic and immunohistochemical appearance of this tumor was identical to that observed for lymph node metastasis (fig. 4). 

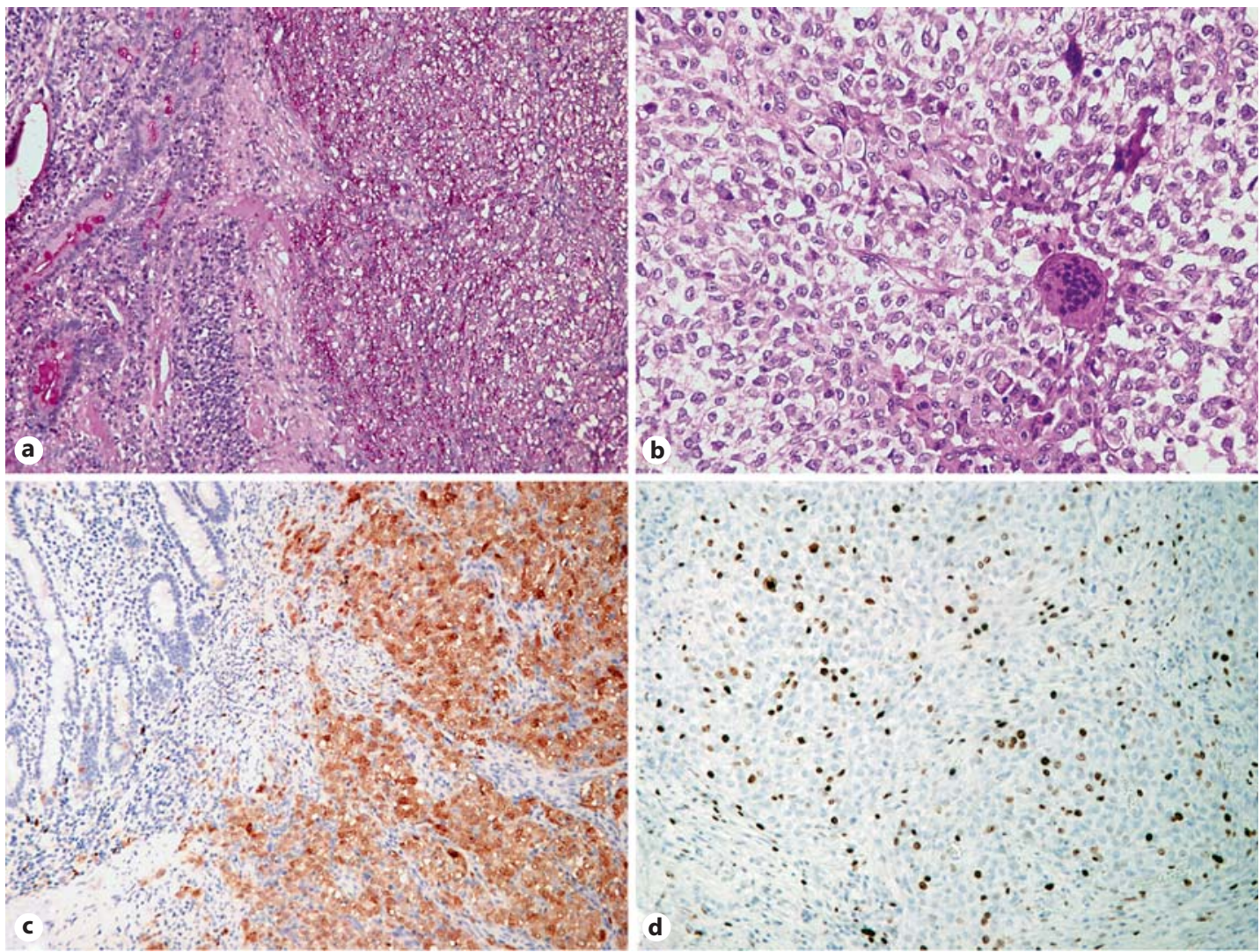

Fig. 4. CCS of the small bowel. a Presence of glycogen in tumor cells, as detected by PAS staining. $\times 200$. b H\&E visualization of multinucleated cells. $\times 400$. c Immunohistochemical staining with S100 polyclonal antibody (dilution 1:2,500, Dako). ×200. d Immunohistochemical staining with Ki-67 (clone MIB-1, dilution 1:250, Dako). $\times 200$.

\section{Discussion}

Several circumstances make this case unusual and therefore deserving presentation. First, though this patient had undergone a decent clinical examination, the primary site of metastatic sarcoma remained unknown until the definite morphological diagnosis was established. Second, while CCS often needs to be discriminated from melanoma, its ES-like appearance is uncommon. This tumor did not express melanocytic markers (melan A, HMB45, MITF) but presented with typical features of ES, including the presence of EWSR1 translocation and Fli-1 expression (fig. 1d, 2a). However, it is important to keep in mind that these characteristics may also occasionally be observed in other tumor types [7-9]; furthermore, the presence of multinucleated cells (fig. 1b, 4b) is somewhat more compatible with CCS than ES diagnosis [3]. Finally, this case exemplifies that the use of anonymous assays, such as break-apart FISH EWSR1 testing, may lead to erroneous results, so the identification of the translocation gene partners is indeed important for proper sarcoma management [10-12]. A series of similar tumors, which were characterized by gastrointestinal location, sarcoma-like histology, absence of melanocytic markers, distinct ultrastructural features and presence of EWSR1 translocations (including EWSR1-ATF1 and EWSR1-CREB1 fusions), has recently been described by Stockman et al. [13]; they suggest to designate this tumor entity as malignant gastrointestinal neuroectodermal tumors. 
In conclusion, this report exemplifies the power of combined imaging-based, morphological, immunohistochemical, cytogenetic and molecular testing in diagnostic oncology.

\section{Acknowledgements}

This work was supported by the Russian Foundation for Basic Research (grants 13-04-92613, 14-0400460, 14-04-92110 and 15-04-01744) and the Dynasty Foundation (contract 18/13).

\section{Disclosure Statement}

The authors disclose no potential conflicts of interest.

\section{References}

1 D'Amico FE, Ruffolo C, Romeo S, Massani M, Dei Tos AP, Bassi N: Clear cell sarcoma of the ileum: report of a case and review of the literature. Int J Surg Pathol 2012;20:401-406.

-2 Shenjere P, Salman WD, Singh M, Mangham DC, Williams A, Eyden BP, Howard N, Knight B, Banerjee SS: Intraabdominal clear-cell sarcoma: a report of 3 cases, including 1 case with unusual morphological features, and review of the literature. Int J Surg Pathol 2012;20:378-385.

3 Fletcher CD, Bridge JA, Hogendoorn PCW, Mertens F (eds): WHO Classification of Tumors of Soft Tissue and Bone. Lyon, IARC, 2013.

4 Lewis TB, Coffin CM, Bernard PS: Differentiating Ewing's sarcoma from other round blue cell tumors using a RT-PCR translocation panel on formalin-fixed paraffin-embedded tissues. Mod Pathol 2007;20:397-404.

5 Huret JL: EWSR1 (Ewing sarcoma breakpoint region 1). Atlas Genet Cytogenet Oncol Haematol. http:// atlasgeneticsoncology.org/. Updated in August 2010. Accessed on January 15, 2014.

-6 Tsukamoto Y, Nakata Y, Futani H, Fukunaga S, Kajimoto K, Hirota S: A rare case of clear cell sarcoma with 4 types of EWSR1-ATF1 fusions detected not in primary site but in metastatic site. Pathol Res Pract 2013;209: 803-807.

7 Sorensen PH, Shimada H, Liu XF, Lim JF, Thomas G, Triche TJ: Biphenotypic sarcomas with myogenic and neural differentiation express the Ewing's sarcoma EWS/FLI1 fusion gene. Cancer Res 1995;55:1385-1392.

-8 Thorner P, Squire J, Chilton-MacNeil S, Marrano P, Bayani J, Malkin D, Greenberg M, Lorenzana A, Zielenska M: Is the EWS/FLI-1 fusion transcript specific for Ewing sarcoma and peripheral primitive neuroectodermal tumor? A report of four cases showing this transcript in a wider range of tumor types. Am J Pathol 1996;148: 1125-1138.

9 Burchill SA, Wheeldon J, Cullinane C, Lewis IJ: EWS-FLI1 fusion transcripts identified in patients with typical neuroblastoma. Eur J Cancer 1997;33:239-243.

10 Mertens F, Antonescu CR, Hohenberger P, Ladanyi M, Modena P, D’Incalci M, Casali PG, Aglietta M, Alvegård T: Translocation-related sarcomas. Semin Oncol 2009;36:312-323.

11 Romeo S, Dei Tos AP: Soft tissue tumors associated with EWSR1 translocation. Virchows Arch 2010;456:219234.

12 Cantile M, Marra L, Franco R, Ascierto P, Liguori G, De Chiara A, Botti G: Molecular detection and targeting of EWSR1 fusion transcripts in soft tissue tumors. Med Oncol 2013;30:412.

13 Stockman DL, Miettinen M, Suster S, Spagnolo D, Dominguez-Malagon H, Hornick JL, Adsay V, Chou PM, Amanuel B, Vantuinen P, Zambrano EV: Malignant gastrointestinal neuroectodermal tumor: clinicopathologic, immunohistochemical, ultrastructural, and molecular analysis of 16 cases with a reappraisal of clear cell sarcoma-like tumors of the gastrointestinal tract. Am J Surg Pathol 2012;36:857-868.

14 Weiss SW, Goldblum JR: Enzinger and Weiss's Soft Tissue Tumors, ed 5. St. Louis, Mosby, 2008. 